\title{
Assessment of Benthic Macro-Invertebrates of Freshwater Ecosystem: A Case Study of Ovia River (Iguoriakhi), Edo State, Nigeria
}

\author{
Louis A. Iyagbaye (MSc.), \\ Rich O. Iyagbaye (MSc.) \\ Department of Environmental Management and Toxicology, \\ University of Benin, Benin City, Nigeria \\ Michael O. Omoigberale (PhD) \\ Department of Animal and Environmental Biology, \\ University of Benin, Benin City, Nigeria
}

doi: 10.19044/esj.2017.v13n26p405 URL:http://dx.doi.org/10.19044/esj.2017.v13n26p405

\begin{abstract}
In this study, the diversity and seasonal variation of benthic macroinvertebrates of Ovia River (Iguoriakhi), Edo State, Southern Nigerian, were studied between July, 2014 and February, 2015. Four stations were selected and sampled monthly and investigated for benthic macro-invertebrates' community structure using basic statistical measurement of abundance and diversity indices to characterize the benthic macro-invertebrates. The species richness, evenness and diversity of the benthic macro-invertebrates in the study area were high and typical of a tropical fast-flowing freshwater river. There was a total of 45 taxa, made up of 1,135 individuals; 10 Ephemeroptera, 10 Diptera, 7 Coleoptera, 7 Odonata, 4 Hemiptera, plasiopora, Haplotaixa, Decapoda, Hydrachnellae, Lepidoptera, Gastropoda, and Trichoptera were represented with a taxa each. The dominant taxa include Ephemeroptera, while the Diptera was the only sub-dominant order identified. Analysis of Variance (ANOVA) revealed that the overall density was significantly different $(\mathrm{P}<0.05)$ in the study stations. A posteriori Duncan Multiple Range (DMR) test indicated that the abundance of Dipterans and Ephemeropterans at station 2 and 4 respectively were the source of the significant difference. The EPT to total ratio indicated that the water quality of all the studied stations were nonimpacted. The study concluded that benthic macro-invertebrates are good candidate and less expensive indices for water quality monitoring.
\end{abstract}

Keywords: Benthic macro-invertebrates, biodiversity, Ovia River, Nigeria 


\section{Introduction}

Benthic macro-invertebrates are organism over $1 \mathrm{~mm}$ in size and these include bottom dwellers which are usually retained by nets or sieves with rush size of about 0.6mm (Macan, 1959). Benthic macro-invertebrate fauna, often referred to as bottom fauna macro-benthos, are those animals that are associated with or live in the bottom of lakes, ponds, rivers, seas, streams, either crawling, burrowing or attacked to various kinds of solid object like boats, canoes, roots of mangrove plants, stones, vegetation, wood and the could be littoral or profundal (Mann, 1980).

Benthic macro-invertebrates are most commonly used tool in biomonitoring. They are invertebrates that inhabit the bottom substrates such as sediments, rocks, snags and aquatic plants, of aquatic habitats for at least part of their life cycle (Sengupta and Dalwani, 2008). There are several advantages of using benthic macro-invertebrates for assessing water quality. According to Sengupta and Dalwani (2008), benthic macro-invertebrates are ubiquitous in rivers and can therefore be affected by environmental disturbances in many different types of aquatic systems and in most habitats/biotopes within these waters. Benthic macro-invertebrates are largely non-mobile and are thus representative of the location being sampled. Their life-span is long enough to allow elucidation of temporal changes caused by disturbances, whilst short enough to ensure observation of recolonisation patterns following such a disturbance. These organisms are also easy to sample and identify. Benthic macro-invertebrates therefore, act as continuous monitors of the water they inhabit (Kalyoncu and Zeybek, 2011), enabling long-term analysis of both regular and intermittent discharges, variable concentrations of pollutants, single and multiple pollutants, and synergistic or antagonistic effects. The use of biota as indicators of stress in the ecosystem has proven successful and indices based on macro-invertebrates assemblages have proven to be useful measures of river health and are widely applied today (Omoigberale and Ogbeibu, 2010; Ogbeibu and Oribhabor, 2002).

Many benthic macro-invertebrates are larval form of flying insects such as mayflies, stoneflies, caddisflies, midge flies etc. The most diverse group of freshwater benthic macro-invertebrates is insects; others are small animals that spend their entire life in streams such as mites and planarians. Some shuttle between water and moist terrestrial environments such as freshwater snail. Benthic macro-invertebrates can be classified as in-fauna and epi-fauna based on immediate substrate of occupation (Cody and Diamond, 1975). In-fauna includes those benthic organisms that are living either buried or burrowing into sediment. Epi-fauna include those that live on the surface of sediments. They are found attached to exposed or submerged object, some are slow moving while others are sedentary. 
Apart from their use as long term indicators of water quality, benthic macro-invertebrates have attracted a lot of interest among biologists in view of their importance in food chain of fishes and other vertebrates. These organisms play a vital role in the circulation and recirculation of nutrients in aquatic ecosystems. They constitute the link between the unavailable nutrients in detritus and useful protein materials in fish and shellfish. Most benthic organisms feed on debris that settle on the bottom of the water and in turn serve as food for a wide range of fishes (Imevbore and Bakare, 1970; Idowu and Ugwumba, 2005).

The aim of the present study is to provide some baseline information on the composition, distribution, taxa richness, general diversity and dominance of the benthic macro-invertebrates in the river and also to assess the quality of the water using benthic macro-invertebrates as bio-indicators.

\section{MATERIALS AND METHODS Study site}

The study was carried out within a stretch of Ovia River (Iguoriakhi), which took it source from the Akpata hills in Ekiti State, Nigeria. Iguoriakhi is located about $23.9 \mathrm{~km}$ from Benin City, off Lagos-Benin Express Road, Nigeria (Lat. 060 $23^{\prime} 42.76^{\prime \prime}$ - $06^{0} 27^{\prime} 10.15^{\prime \prime} \mathrm{N}$; Long 005 $25^{\prime} 55.0^{\prime \prime}-$ $\left.005^{0} 29^{\prime} 36.20 " \mathrm{E}\right)$, within the tropical rainforest belt of Nigeria. This region has two distinct regions: wet and dry season, which starts from April to October and November to March respectively. The vegetation is predominantly shrubs and trees.

Four sampling stations were selected: 1 and 2 (upstream) and 3 and 4 was designated downstream, each station were about $0.5 \mathrm{~km}$ apart. Station 1 is located upstream about $1 \mathrm{~km}$ from a bridge across the river. The station is partially shaded by trees forming a canopy over it. The substratum is a mixture of sandy and decaying organic materials at the bank of the river. Anthropogenic activity is solely fishing. Station 2 is about $0.5 \mathrm{~km}$ downstream of station 1. The substratum is composed of mud with decaying organic materials at the bank of the river. Human activities include bathing, laundry, dredging, Lumbering and fishing. 


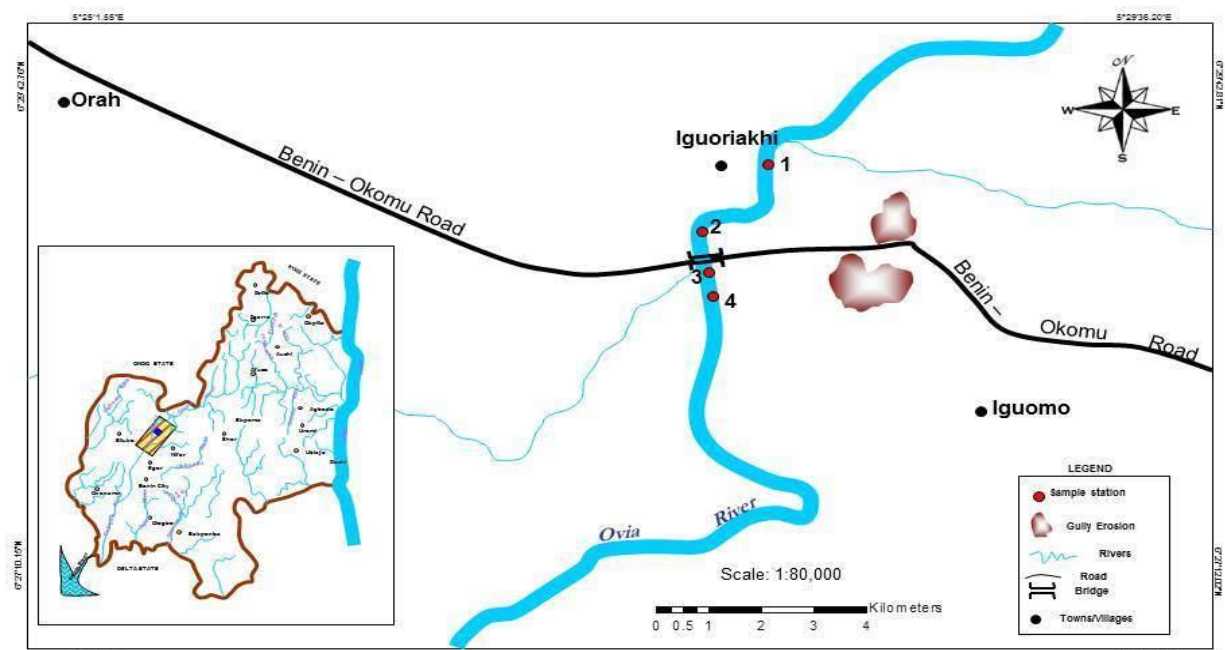

Fig 1: Map of the study area showing location of Ovia River and the sampling stations, with map of Edo State.

Station 3 is about $1.5 \mathrm{~km}$ downstream of station 1 . The average depth of the river at this station is $1.45 \pm 0.62 \mathrm{~m}$. The current velocity of flow is $0.71 \mathrm{~m} / \mathrm{s}$. The major activity here is fishing and farming at the bank of the river. It is characterized by floating macropytes such as the Eichhornia crassipes and Salvinia sp. and the bank is made up of grass mats and few palm trees. Station 4 is located about $2 \mathrm{~km}$ downstream of station 1 (latitude $6^{\circ} 28^{\prime} 44.9^{\prime}$ 'N and longitude $5^{\circ} 27^{\prime} 43.5^{\prime}$ 'E). The flow rate is minimal at this station, with mean flowing velocity of $0.62 \mathrm{~m} / \mathrm{s}$. The average depth at this station is about $1.46 \pm 0.48 \mathrm{~m}$. The dominant terrestrial vegetation here includes Elaeis guineensis and grass vegetation. The activities witnessed here include, fishing only. The substratum composes of decaying plant materials with little organic matter and with clay.

Sampling for Benthic macro-invertebrates, which spanned from July, 2014 to February, 2015 was conducted monthly at the study stations between $0730 \mathrm{~h}$ and $1100 \mathrm{~h}$ on each sampling day. The benthic macro-invertebrates were collected by Kick sampling technique (Hynes, 1970; Peterson and Fernando, 1970; Ogbeibu and Victor 1989) and dusting of Echhornia crassipes. The substratum in a known area of $0.25 \mathrm{~m}^{2}$ in each station was vigorously disturbed by kicking for a few minutes. The dislodged organisms in the course of the disturbance were sampled with a hand net made of a cone shaped $100 \mu \mathrm{m}$ mesh size, with a mouth diameter of $20 \mathrm{~cm}$ and a detachable handle by placing it opposite the flow direction of the river. The dislodged organisms were then washed into the net. Samples collected were sieved with a set of Tyler sieves of mesh sizes $2 \mathrm{~mm}, 1 \mathrm{~mm}, 150 \mathrm{um}$ and $100 \mathrm{um}$ respectively. The contents retained in the sieves were washed into polypropylene bottle and preserved in 
$10 \%$ formalin. Benthic macro-invertebrates were sorted under a binocular microscope (American Optical Corporation model 570), while identification, counting and drawing were done using an Olympus Vanox Research Microscope Model 230485 (Mag. 50-500x). Identification of specimens of benthic macro-invertebrates was carried out using manuals listed in Ogbeibu and Victor (1989).

\section{Data Analysis}

The benthic macro-invertebrates characterizing and similarities were according to Omoigberale and Ogbeibu (2010). The single factor Analysis of Variance (ANOVA) and Duncan Multiple Range test were used to test for significant difference in the density of benthic macro-invertebrates among stations and to locate site(s) of significant difference respectively. All statistics procedures were adopted from Zar (1984) as well as SPSS 20.00 computer package.

\section{RESULTS}

\section{CHECKLIST OF BENTHIC MACRO-INVERTEBRATES}

The benthic macro-invertebrates comprises of Forty-five (45) taxa consisting of species each of 10 Ephemeroptera, 10 Diptera, 7 Coleoptera, 7 Odonata, 4 Hemiptera, plasiopora, Haplotaixa, Decapoda, Hydrachnellae, Lepidoptera, Gastropoda, and Trichoptera

$\begin{array}{ll}\text { Phylum } & \text { Annelida } \\ \text { Class: } & \text { Oligochaeta } \\ \text { Order: } & \text { Plesiopora }\end{array}$

Family: Naididae

$\begin{array}{ll}\text { Class: } & \text { Clitellata } \\ \text { Order: } & \text { Haplotaxida }\end{array}$

Family: Lumbricidae

Eiseniella tetradra

Phylum:

Class:

Subclass:

Order:

Family: Atyidae

Class:

Arthropoda

Order: Hydrachnellae

Arachnida

Crustacea

Malacostraca

Decapoda

Caridina africana

Kingsley, 1882

Class: Insecta

Order: Ephemeroptera

Family: Caenidae

Family: Baetidae

\section{Caenis sp.}


Baetis bicaudatus

Leach

Cloeon simplex.

Cloeon cylindroculum

Centroptilum sp.

Kimmins

Family: Adenophlebiodes

Adenophlebiodes

Ulmer

Family: Siphlonuridae

Family: Leptophlebiidae

Siphlonura sp

Needham

Family: Dicercomyzidae

Leptoplebia sp

Order:

Dicercomyzon $\mathrm{sp}$

Demoulin

Family: Dytiscidae Coleoptera

Eaton

Amphiops gibbos

Family: Hydrophilidae

Philhydrus pectoralis

Family: Dytiscidae

Deronectes elegaris

Dytiscus vertifolis

Family: Elmidae

Dubiraphia sp.

Family: Noteridae

Hydrocanthus sp.

Family: Helmidae

$$
\text { promeresia sp. }
$$

Order: Hemiptera

Family: Naucoridae

pelocoris femoratus

Family: Notonectidae

Notonecta unifasciata

Family: Gerridae

Gerris lacustris

Family: Belostomatidae

Lethocerus sp

Order: Lepidoptera

Family: Crambidae

Order:

Nymphula sp

Family: Chironomidae

$$
\begin{aligned}
& \text { Ablabesmyla } \mathrm{sp} \\
& \text { Chironomus fractilobus } \\
& \text { Pentaneura } \mathrm{sp} \\
& \text { Polypedilum } \mathrm{sp} \\
& \text { Tanypus } \mathrm{sp} \\
& \text { Clinotanypus maculates } \\
& \text { Cardiocladius } \mathrm{sp}
\end{aligned}
$$

Procladius sp

Kieffer

Kieffer, 1913 
Family: Culicidae

\section{Tendipes tentans}

Order: Odonata

$$
\text { Culex sp }
$$

Sub order: Anisoptera

Family: Corbuliidae

Family: Libellulidae

$$
\text { Oxygaster curtisil }
$$

Sub family: Libellulinae

Family: Aeshnidae

$$
\text { Libellula sp }
$$

Aeshna sp

Erythemis sp

Sub order: Zygoptera

Family: Lestidae

Family: Coenagrionidae

\section{Lestes $s p$}

Coenagrion scitilum

Enallagma sp.

Charpentier

Rambur

PHYLUM: MOLLUSCA

Class: Gastropoda

Superfamily: Ampullarioidea

Family: Ampullariidae

Species:

\section{Benthic macro-invertebrates}

Table 1 shows the taxa composition, density and distribution of benthic macro-invertebrates in the study area. Forty-five taxa were identified from a total of 1,135 individuals collected. The major benthic macro-invertebrates include:

Annelida: This phylum was represented by 2 species; Nais sp and Eiseniella tetradra in all stations. Nais sp was recorded at stations 1 and 4, while Eiseniella tetradra was encountered only at station 1 (Table 2).

Diptera: The family chironomidae was the most important across the study stations, contributing $7.14 \%$ to the total density of benthic macroinvertebrates recorded (Fig. 1). The dominant taxon was pentaneura sp. It was dominating all the stations. The chironomidae was represented by 9 taxa. Analysis of Variance (ANOVA) revealed that the density of diptera at station 2 was significantly higher $(\mathrm{P}<0.01)$ than those in stations 1,3 and 4 which were not significantly different $(\mathrm{P}>0.05)$ from each other (Table 3$)$. 
Table 1: Summary of the physical and chemical parameters of sediment of Ovia River

\begin{tabular}{|c|c|c|c|c|c|c|c|}
\hline & Station 1 & Station 2 & Station 3 & Station 4 & & & \\
\hline Parameters $(n=29)$ & $($ Min-Max) $\bar{x} \pm \mathrm{SD}$ & $($ Min-Max) $\bar{x} \pm$ SD & $($ Min-Max) $\bar{x} \pm$ SD & $($ Min-Max $) \bar{x} \pm \mathrm{SD}$ & p-Value & NESREA & WHO \\
\hline Water Temperature ${ }^{0} \mathrm{C}$ & (21.00-28.50) 23.94 \pm 4.83 & (22.00-28.00) $24.00 \pm 4.78$ & (20.00-29.00) $25.08 \pm 4.83$ & (23.00-29.00) $24.75 \pm 5.06$ & $\mathrm{p}>0.05$ & $35^{\circ} \mathrm{C}$ & N/A \\
\hline $\mathrm{pH}$ & $(5.20-6.20) 5.78^{\mathrm{a}} \pm 0.32$ & $(4.60-5.50) 5.15^{\mathrm{b}} \pm 0.33$ & $(4.50-5.90) 5.30^{\mathrm{b}} \pm 0.45$ & $(5.30-6.00) 5.73^{\mathrm{a}} \pm 0.24$ & $\mathrm{p}<0.01$ & $6.5-8.5$ & $\begin{array}{l}6.5- \\
8.5\end{array}$ \\
\hline $\begin{array}{l}\text { Electrical Conductivity } \\
(\mu \mathrm{S} / \mathrm{cm})\end{array}$ & $\begin{array}{l}(90.00-250.00) 193.13^{\mathrm{b}} \\
\pm 63.30\end{array}$ & $\begin{array}{l}(260.00-450.00) 367.50^{a} \\
\pm 69.64\end{array}$ & $\begin{array}{l}(220.00-380.00) 313.75^{\mathrm{a}} \\
\pm 53.97\end{array}$ & $\begin{array}{l}(130.00-280.00) 222.50^{b} \\
\pm 47.13\end{array}$ & $\mathrm{p}<0.01$ & N/A & 1000 \\
\hline Organic Carbon $(\%)$ & $(0.62-1.50) 1.07^{\mathrm{b}} \pm 0.30$ & $(2.11-4.30) 3.35^{\mathrm{a}} \pm 0.89$ & $(1.72-2.95) 2.17^{\mathrm{b}} \pm 0.51$ & $(0.81-1.57) 1.24^{\mathrm{b}} \pm 0.22$ & $\mathrm{p}<0.01$ & NA & NA \\
\hline Total Nitrogen (\%) & $(0.06-0.16) 0.10^{\mathrm{b}} \pm 0.04$ & $(0.19-0.40) 0.31^{\mathrm{a}} \pm 0.08$ & $(0.15-0.29) 0.21^{\mathrm{b}} \pm 0.05$ & $(0.07-0.15) 0.12^{\mathrm{b}} \pm 0.03$ & $\mathrm{p}<0.01$ & NA & NA \\
\hline $\begin{array}{l}\text { Exchangeable Anions } \\
\text { (meq/100g) }\end{array}$ & $(0.30-0.90) 0.61^{\mathrm{b}} \pm 0.22$ & $(0.50-1.60) 1.08^{\mathrm{a}} \pm 0.38$ & $(0.50-1.30) 0.81^{\mathrm{ab}} \pm 0.25$ & $(0.20-0.90) 0.61^{\mathrm{b}} \pm 0.25$ & $\mathrm{p}<0.01$ & NA & NA \\
\hline Sodium $(\mathrm{meq} / 100 \mathrm{~g})$ & (0.16-0.89) $0.55 \pm 0.29$ & $(0.42-1.60) 1.09 \pm 0.50$ & $(0.35-1.45) 0.96 \pm 0.48$ & $(0.22-1.15) 0.69 \pm 0.41$ & $\mathrm{p}>0.05$ & 200 & 200 \\
\hline Potassium(meq/100g) & $(0.05-0.15) 0.11^{\mathrm{c}} \pm 0.03$ & $(0.15-0.40) 0.28^{\mathrm{a}} \pm 0.08$ & $(0.10-0.25) 0.17^{\mathrm{b}} \pm 0.04$ & $(0.05-0.15) 0.10^{c} \pm 0.03$ & $\mathrm{p}<0.01$ & NA & NA \\
\hline Calcium (meq/100g) & $(0.91-2.00) 1.50^{\mathrm{a}} \pm 0.42$ & $(1.76-4.28) 3.35^{\mathrm{a}} \pm 1.04$ & $(1.30-3.18) 2.60^{\mathrm{b}} \pm 0.74$ & $(1.11-2.35) 1.93^{c} \pm 0.50$ & $\mathrm{p}<0.01$ & NA & NA \\
\hline Magnesium(meq/100g) & $(0.39-0.95) 0.68^{\mathrm{b}} \pm 0.21$ & $(0.72-1.38) 1.12^{\mathrm{a}} \pm 0.27$ & $(0.39-1.35) 0.97^{\mathrm{ab}} \pm 0.38$ & $(0.27-0.95) 0.70^{\mathrm{b}} \pm 0.24$ & $\mathrm{p}<0.01$ & NA & NA \\
\hline Chloride $(\mathrm{mg} / \mathrm{kg})$ & $(17.70-31.60) 25.50^{c} \pm 5.78$ & $(29.20-55.60) 44.79^{a} \pm 10.16$ & $(22.10-42.90) 36.40^{\mathrm{b}} \pm 7.71$ & $(17.70-34.40) 27.66^{c} \pm 6.67$ & $\mathrm{p}<0.01$ & 600 & NA \\
\hline Phosphate $(\mathrm{mg} / \mathrm{kg})$ & $(3.23-6.89) 5.75^{\mathrm{c}} \pm 1.41$ & $(7.08-9.82) 8.70^{\mathrm{a}} \pm 0.86$ & $(5.49-8.15) 7.20^{\mathrm{b}} \pm 0.93$ & $(3.38-7.78) 5.81^{c} \pm 1.46$ & $\mathrm{p}<0.01$ & 10 & NA \\
\hline $\begin{array}{l}\text { Ammonium Nitrogen } \\
(\mathrm{mg} / \mathrm{kg}\end{array}$ & $(1.23-1.95) 1.65^{c} \pm 0.28$ & $(5.16-8.25) 6.69^{\mathrm{a}} \pm 1.05$ & $(2.94-8.10) 5.78^{\mathrm{a}} \pm 1.72$ & $(1.95-4.20) 3.25^{\mathrm{b}} \pm 0.87$ & $\mathrm{p}<0.01$ & NA & NA \\
\hline Nitrite $(\mathrm{mg} / \mathrm{kg})$ & $(0.42-1.55) 1.16^{\mathrm{b}} \pm 0.38$ & $(1.12-2.89) 1.97^{\mathrm{a}} \pm 0.52$ & $(0.98-2.52) 1.71^{\mathrm{a}} \pm 0.45$ & $(0.68-1.41) 0.98^{\mathrm{b}} \pm 0.27$ & $\mathrm{p}<0.01$ & NA & NA \\
\hline
\end{tabular}




\begin{tabular}{|c|c|c|c|c|c|c|c|}
\hline Nitrate $(\mathrm{mg} / \mathrm{kg})$ & $(1.69-4.00) 3.08^{\mathrm{c}} \pm 0.90$ & $(4.11-6.95) 5.74^{\mathrm{a}} \pm 0.93$ & $(3.64-5.67) 4.49^{\mathrm{b}} \pm 0.92$ & $(1.63-3.62) 3.07^{\mathrm{c}} \pm 0.72$ & $\mathrm{p}<0.01$ & 10 & NA \\
\hline Sulphate (mg/kg) & $(2.45-5.75) 4.55^{b} \pm 1.15$ & $(6.12-9.57) 8.01^{\mathrm{a}} \pm 1.12$ & $(5.58-7.75) 7.10^{\mathrm{a}} \pm 0.84$ & $(2.84-6.48) 4.72^{b} \pm 1.21$ & $\mathrm{p}<0.01$ & 1000 & NA \\
\hline Clay $(\%)$ & $(3.20-7.91) 5.71^{\mathrm{b}} \pm 1.55$ & $(5.50-10.90) 8.59^{\mathrm{a}} \pm 2.00$ & (4.30-9.90) $7.13^{\mathrm{ab}} \pm 2.06$ & $(4.80-7.50) 5.34^{\mathrm{b}} \pm 0.90$ & $\mathrm{p}<0.01$ & NA & NA \\
\hline Silt $(\%)$ & $(1.30-3.15) 2.46^{b} \pm 0.61$ & $(2.80-4.90) 3.74^{\mathrm{a}} \pm 0.83$ & $(2.10-2.80) 2.50^{\mathrm{b}} \pm 0.31$ & $(1.60-2.90) 2.44^{\mathrm{b}} \pm 0.42$ & $\mathrm{p}<0.01$ & NA & NA \\
\hline Sand $(\%)$ & $(89.10-94.80) 91.80^{\mathrm{a}} \pm 2.01$ & $(77.50-91.20) 86.69^{b} \pm 4.20$ & $(86.90-93.60) 90.36^{\mathrm{a}} \pm 2.20$ & $(90.00-93.60) 92.13^{\mathrm{a}} \pm 1.12$ & $\mathrm{p}<0.01$ & NA & NA \\
\hline
\end{tabular}




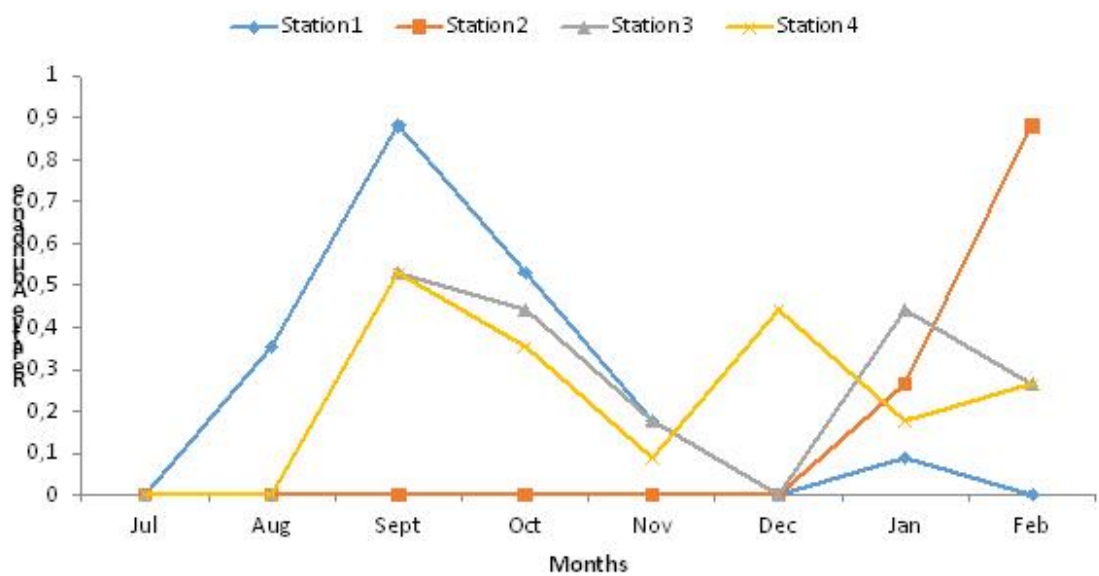

Fig 2: Temporal and spatial variations in Diptera at the study stations

Ephemeroptera: The family adenophlebiidae and baetidae dominated the samples at all stations, contributing $22.2 \%$ and $77.78 \%$ in station $1,24.07 \%$ and $75.93 \%$ in station 2, 50.96\% and $49.04 \%$ in station 3 and $36.97 \%$ and $63.03 \%$ in station 4 . It was represented by 8 taxa from 4 families, Baetidae (5), Adenophlebiidae (1), Leptophlebiidae (1), and Siphlonuridae (1). The most dominated taxa were adenophlebiodes $\mathrm{sp}$, cloeon simplex, and centroptilum $\mathrm{sp}$. (Fig.3). They each recorded their highest abundance at stations 3, 2 and 1 respectively. A posteriori test for multiple comparison showed that the density of ephemeroptera at station 4 was significantly higher $(\mathrm{P}<0.01)$ than those at stations 1,2 , and 3 , which were not significantly different from each other (Table 3 ).

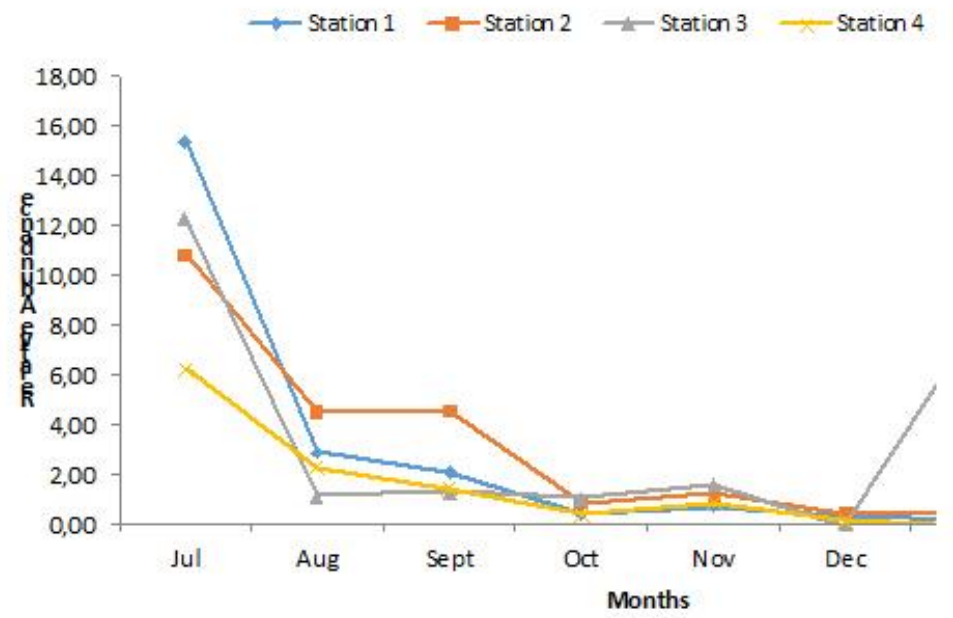

Fig 3: Temporal and spatial variations in Ephemeroptera at the study stations 


\section{DISCUSSION}

Physico-chemical, geomorphic and biotic characteristic of the aquatic ecosystem are the most significant factors influencing the species composition, abundance and distribution of aquatic benthic macroinvertebrates (Ibemenuga and Inyang, 2006). Bishop (1973) and Dance and Hynes (1980) asserted that water quality and abundance of nutrient were the major factors governing the abundance and distribution of benthic macroinvertebrates fauna in aquatic environment.

A total of 45 species comprising of 1,135 individuals shared within 3 phyla, 6 classes, 11 orders and 32 families were recorded in this study. This recorded species richness is similar to some of works carried out in a similar pattern by: Victor and Ogbeibu (1991); Ogbeibu and Victor (1989); Victor and Onomivbori (1996) and Ogbeibu and Oribhabor (2002) at Ikpoba River. This result varied from a total of 23 species identified by Umeozor (1995) at the new Calabar River; 30 species belonging to 20 families and 5 classes recorded by Hart and Zabbey (2005) at Woji Creek in the upper reaches of Bonny River in the Lower Niger Delta; 14 species representing 11 families of macro invertebrates identified by Sikoki and Zabbey (2005) at Imo River; 19 species belonging 4 phyla, 6 classes and 12 families were identified by George et al. (2009) at Okpoka creek during the study and 28 species identified by Ezekiel et al. (2011) at Sombreiro River, Niger Delta. These differences are attributable to difference in location, time, nutrient availability and prevailing physical and chemical characteristics of these aquatic bodies. The variable substrate composition (sand, mud, silt, debris/organic detritus, stones etc.) and aquatic macrophyte provided different microhabitats for the diverse groups of the fauna. Organisms cannot survive without adequate food for the organisms' survival and growth (Ibemenuga and Inyang, 2006). The account of dominant taxa which include Ephemeroptera and Diptera in this study have been in the documentation by Ogbeibu and Orihabor (2002) at Ikpoba River ; Olomukoro and Ezemonye (2006) in assessment of the macro-invertebrate fauna of rivers in southern Nigeria; Olomukoro and Azubuike (2009) at Ekpan Creek, Warri. The occurrence of Ephemeroptera (Baetidae) and Diptera (Chironomidae) have been reported to be common and major components of tropical streams (Victor and Ogbeibu, 1989; Ogbeibu and Victor, 1989; Victor and AlMahrouqi, 1996).

Ephemeropterans appeared at all stations; the density was most and least felt at stations 3 and 4 respectively. The ephemeropterans encountered in this study have earlier been recorded by Ogbeibu and Victor (1989), Ogbeibu and Oribhabor, (2002) at Ikpoba River, Edokpayi and Ekikhalo (2001) at Ibiekuma River, Omoigberale and Ogbeibu (2010) at Osse River. The qualitative presence of Ephemeroptera in almost all the water bodies in Edo State as being spectacular has being acknowledged (Olomukoro and 
Ezemonye 2006). Contrary to the documentations by Ogbeibu and Oribhabor (2002) and Omoigberale and Ogbeibu (2010) which recognized Baetis tricaudatus and Baetis bicaudatus respectively as most dominant ephemeropterans at the various study rivers, Adenophlebiodes sp. was recorded as the most dominant ephemeropterans in this study. Cloeon simplex and Centroptilum sp. which are current loving were encountered visually at all the stations. Significant correlation was recorded between members of the family Baetidae and Caenidae with total hydrocarbon content of the sediment. The dominance of the dipterans with respect to number of individuals and species is in agreement with the reports of Victor and Ogbeibu (1989), Ogbeibu and Oribhabor (2002), Ogbeibu and Oribhabor (2002), Ibemenuga and Inyang (2006), Edokpayi et al. (2010). The dominance of dipterans in the system as in other aquatic ecosystems may be attributed to their morphological and physiological adaptations to the various habitats, availability of food and sustained reproduction (Mbah and Vijime, 1989; Umeham, 1989). Chironomids which were among the invertebrates that accounted most in the overall abundance of the dipterans are known to colonize all kinds of environments including polluted waters. They hardly show any habitat restriction (Victor and Ogbeibu, 1991) and are known to replace other invertebrate taxa in streams perturbed by human activity. This is due to their ability to extract oxygen from water of very low oxygen concentration. The presence of the dipterans was felt at all stations; their density varies across the study stations. The variable substrate composition which provided different microhabitats and nutrient variability may be responsible for this density differences. Significant inverse correlation was recorded between members of the family Chironomidae and the sediments nitrite concentration; probably reduction in the concentration of these $\mathrm{NO}_{2}$ leads increase in the density of chironomids.

The trichopterans were sparsely represented among the study stations; this probably resulted from high sensitivity of these organisms to organic pollution. Species of annelid recorded in this study have been documented by Olomukoro and Ezemonye (2006); Omoigberale and Ogbeibu (2010). Members of the order Plesiopora were represented by Nais sp. and Eiseniella tetradra which were also sparely represented this was in contrast to the overall abundance of annelids in aquatic ecosystem that was recognized by Omoigberale and Ogbeibu (2010). The annelids identified in this study were not among the enlisted species recognized by Ajao and Fagade (1991) and George et al., (2010). Decapoda had been recognized to be intolerant to induced environmental disturbance Ogbeibu and Oribhabor (2002). Species of decapods recognized in this study have been documented by Ogbeibu and Oribhabor (2002) at Ikpoba River, Omoigberale and Ogbeibu (2010) at Osse River, Olomukoro and Ezemonye (2006) in the study of aquatic invertebrates 
at Southern Nigeria. Abundance and taxa richness of the order of Odonata encountered in this study were unevenly distributed across the station. Their presence were felt most at stations 4 and most of the Odonata identified in this study have been in the literatures documented by Olomukoro and Ezemonye (2006); Omoigberale and Ogbeibu (2010). The rest of the benthic macroinvertebrates which include decapods, hemipterans and coleopterans identified in this study have been documented most of the above referenced scientists.

Table 2: Abundance and Distribution of Benthic macro-invertebrates at the study stations

\begin{tabular}{lcccc}
\hline & Station & Station & Station & Station \\
& $\mathbf{1}$ & $\mathbf{2}$ & $\mathbf{3}$ & $\mathbf{4}$ \\
\hline ANNELIDA & - & - & - & - \\
Plesiopora & - & - & - & - \\
Nais sp & 1 & - & - & 1 \\
Haplotaxida & - & - & - & - \\
Eiseniella tetradra & 1 & - & - & - \\
ARTHROPODA & - & - & - & - \\
Decapoda & - & - & - & - \\
Caridina africana & 2 & 2 & 1 & - \\
Hydrachnellae & - & - & - & - \\
Argyroneta aquarica & 1 & - & 1 & - \\
Trichoptera & - & - & - & - \\
Agraylea sp. & - & - & 1 & - \\
Ephemoroptera & - & - & - & - \\
Adenophlebiodes sp. & 52 & 52 & 133 & 44 \\
Cloeon cylindrolum & - & 5 & 2 & 3 \\
Leptoplebia sp. & 3 & - & - & - \\
Siphlonura sp. & 2 & 1 & - & 2 \\
Cloeon simplex & 28 & 72 & 22 & 13 \\
Pseudocloeon sp. & - & - & 8 & - \\
Baetis sp & 52 & - & 8 & 13 \\
Centroptilum sp & 97 & 86 & 88 & 44 \\
Caenis sp & 23 & 16 & - & 3 \\
Dicercomyzon sp & - & 36 & 35 & 8 \\
Coleoptera & - & - & - & - \\
Amphiops gibbos & 2 & - & - & - \\
Philhydrus pectoralis & 4 & - & 1 & 2 \\
Deronectes elegaris & 1 & - & - & - \\
Dytiscus vertifolis & - & 1 & 29 & 1 \\
Dubiraphia sp. & 1 & - & - & - \\
Hydrocanthus sp & - & - & - & 2 \\
Promeresia sp & - & - & 1 & - \\
Hemiptera & - & - & - & - \\
Pelocoris femoratus & - & 2 & 3 & 1 \\
Notonecta unifasciata & - & - & 1 & - \\
& & & &
\end{tabular}




\begin{tabular}{lcccc} 
Gerris lacustris & - & 1 & - & - \\
Lethocerus sp. & - & 2 & - & - \\
Lepidoptera & - & - & - & - \\
Nymphula sp. & - & 1 & - & - \\
Diptera & - & - & - & - \\
Ablabesmyla sp & 12 & 3 & 2 & 2 \\
Chironomus fractilobus & - & 2 & 3 & 2 \\
Pentaneura sp & 10 & 8 & 16 & 14 \\
Polypedilum sp. & 1 & - & - & - \\
Tanypus Sp. & - & - & - & 1 \\
Polypedilum sp & - & - & 1 & - \\
Clinotanypus & & & & \\
maculates & - & - & 1 & - \\
Cardiocladius sp. & - & - & - & 1 \\
Procladius sp & - & - & - & - \\
Tendipes tentans & - & - & - & 1 \\
Culex sp. & - & - & 3 & - \\
Odonata & - & - & - & - \\
Oxygaster curtisil & - & - & - & 2 \\
Libellula sp & - & - & - & 2 \\
Aeshna sp & 1 & - & - & 2 \\
Erythemis sp & - & - & - & 1 \\
Lestes sp & 3 & 7 & 4 & 5 \\
Enallagma sp. & 2 & 1 & - & 2 \\
Coenagrion Scitulum & 1 & 1 & 1 & - \\
MOLLUSCA & - & - & - & - \\
Gastropoda & - & - & - & - \\
Pila ovata & - & - & 1 & - \\
\hline Number of species (S) & 22 & 19 & 22 & 25 \\
Numbers of Individuals & & & & \\
(N) & 300 & 299 & 364 & 172 \\
Dominance (D) & 0.18 & 0.19 & 0.21 & 0.15 \\
Diversity (H) & 2.07 & 1.97 & 1.97 & 2.35 \\
Equitability (J) & 0.67 & 0.67 & 0.64 & 0.73 \\
Evenness (E) & 0.36 & 0.38 & 0.33 & 0.42 \\
Species richness & & & & \\
(Margalef) & & & & 4.66 \\
\hline
\end{tabular}

Species diversity is known to be highly variable in rivers with response to disturbance, nutrients availability and the presence of suitable habitat (Fowler, 2002). Higher diversity also results when many species have equal or near-equal opportunity of co-existence. Mckintosh (2000), in support of this, observed that in the absence of disturbance, community composition may be strongly influenced by biotic interactions such as competition and predation. A decrease in diversity and corresponding increase in abundance of a limited number of species is a common community response to environmental disturbance. The diversity and evenness of species calculated 
by Shannon-Wiener function varied among the study stations. Station 4 had the highest diversity index as calculated by Shannon-Wiener function; this reflects the evenly distribution of these organisms encountered at this station. The high evenness and low dominance index justify this situation, since the higher the evenness the higher the diversity, and the lower the dominance index, the higher the diversity (Victor and Ogbeibu 1989).

Table 3: Summary of Taxa Composition and Test of Significant Difference

\begin{tabular}{llcccccc}
\hline & Station 1 & Station 2 & Station 3 & Station 4 & $\begin{array}{c}\text { Chi- } \\
\text { Square }\end{array}$ & $\begin{array}{c}\text { p- } \\
\text { Value }\end{array}$ \\
\hline Dominant & Ephemeroptera & $257^{\mathrm{a}}$ & $268^{\mathrm{a}}$ & $296^{\mathrm{a}}$ & $130^{\mathrm{b}}$ & 68.51 & $\mathrm{p}<0.01$ \\
Subdominant & Diptera & $23^{\mathrm{a}}$ & $13^{\mathrm{b}}$ & $21^{\mathrm{a}}$ & $21^{\mathrm{a}}$ & 16.69 & $\mathrm{p}<0.01$ \\
Rare & Rare Taxa & $20^{\mathrm{b}}$ & $18^{\mathrm{b}}$ & $47^{\mathrm{a}}$ & $21^{\mathrm{b}}$ & 21.32 & $\mathrm{p}<0.01$ \\
Total & & $300^{\mathrm{a}}$ & $299^{\mathrm{a}}$ & $364^{\mathrm{a}}$ & $172^{\mathrm{b}}$ & 68.46 & $\mathrm{p}<0.01$ \\
\hline
\end{tabular}

The benthic macro-invertebrates' comparisons of the four stations clearly showed that station 3 and station 4 have the highest and lowest abundance respectively which can be attributed to nutrient availability, response to disturbance and the presence of suitable habitats.

From biological analyses of the studied water body with spatial environmental conditions, it is concluded that benthic macro-invertebrates are good candidates to be used as bio-monitoring of water quality and environmental conditions of freshwater bodies.

\section{References:}

1. Ajao, F.A and Fagade, S.O. (1991). A Study of Sediments Communities in Lagos Lagoon, Nigeria. J. Oil chem. Pollut. 7: 85-105.

2. Bishop, O. N. (1973). Limnology of a small Malayan River, Sungai Gomback W. J. Junk. Hague. 485pp.

3. Cody, M. L., and Diamond J. M. (1975) Ecology and Evolution of Communities. Belknap Press of Harvard University . 543pp.

4. Dance, K. W. Hynes, H. B. N. (1980). Some effects of Agricultural land use on stream insect communities Environmental Pollution Series., 22: $19-28$.

5. Edokpayi C. A. and Ekikhalo C. O. (2001). Hydrobiological studies on Ibiekuma River at Ekpoma, southern Nigeria, after impoundment: the faunal characteristics. African Journal of Science and Technology (AJST) Science and Engineering Series 2 (1) 72-81.

6. Edokpayi, C.A., Olowoporoku, A.O and Uwadiae (2010). The hydrochemistry and macro benthic fauna characteristics of an urban draining creek. International Journal of Biodiversity and Conservation. 2(8):196-203. 
7. Ezekiel, E. N., Hart, A. I. and Abowei, J. F. N. (2011). The Distribution and Seasonality of Benthic Macro-Invertebrates in Sombreiro River, Niger Delta, Nigeria. Research Journal of Applied Sciences, Engineering and Technology 3(4): 264-271.

8. Fowler, R.T. (2002). Relative importance of surface and sub-surface movement of benthic community recovery in the Makarerie River. North Island, New Zealand. New Zealand Journal of Marine and Freshwater Resources 36:459-48.

9. George, A. D. I. Abowei, J. F. N. and Daka E. R. (2009). Benthic macro invertebrate fauna and physico-chemical parameters in Okpoka creek sediments, Niger Delta, Nigeria. International journal of animal and veterinary advances 1(2): 59-65.

10. George, A. D. I., Abowei, J. F. N., Alfred-Ockiya J. F. (2010). The distribution, abundance and seasonality of benthic macro invertebrate in Okpoka creek sediments, Niger Delta, Nigeria. Research Journal of Applied Sciences Engineering and Technology, 2(1): 11-18.

11. Hart, A. I. and Zabbey, N. (2005). Physico-chemical and benthic fauna of Woji Creek in the Lower Niger Delta, Nigeria. Environ. Ecol., 23(2): 361-368.

12. Hynes, H.B.N.(1970) the invertebrate fauna of welsh mountain stream. Arch. Hydrobiol. 57:344-388

13. Ibemenuga, K. N. and Inyang, N. (2006). Macroinvertebrate Fauna of a Tropical Freshwater Stream in Nigeria. Animal Research International 3(3): $553-561$

14. Idowu, E.O. and A.A.A. Ugwumba, (2005). Physical, chemical and faunal characteristics of a Southern Nigeria Reservoir. The Zoologist Vo., 3: 15-25.

15. Imevbore, A.M.A. and O. Bakare, (1970). The food and feeding habits of non-cichlid fishes of the River Niger in the Kainji Reservoir area in Kainji - A Nigerian Man-Made Lake, Kainji Lake Studies. Ecology, 7: 87-98.

16. Kalyoncu, H. and M. Zeybek, 2011. An application of different biotic and diversity indices for assessing water quality: A case study in the Rivers Çukurca and Isparta (Turkey). Afr. J. Agric. Res., 6(1): 19-27.

17. Macan, T.T (1959) A guide on freshwater veterbrates, Longman publishers London. 118pp

18. Mckintosh, A.B. (2000). Aquatic predators-prey interaction. In: New Zealand Stream invertebrates: Ecology and Imlication for management. New Zealand Limnological Society.

19. Mann, K.H (1980) Benthic Secondary production in: Mann, K.H et al (Ed) (1980) Fundamentals of aquatic ecosystems. Pp. 103-188 
20. Mbah, C. E. and Vijime, C. G. (1989). Preliminary Taxonomic survey of fresh water insects from northern Nigeria. Journal of Aquatic Sciences, 4: 27 - 39.

21. Ogbeibu, A. E. and Victor, R. (1989). The effects of road and bridge construction on the bankroot macroinvertebrates of a southern Nigerian stream. Environ Pollut; 56: 85-100.

22. Ogbeibu, A.E. and Oribhabor (2002). Ecological impacts of river impoundments using benthic macro invertebrates as indicators. Water Research 36: 2427-2436.

23. Olomukoro, J. O. and Azubuike, C. N. (2009). Heavy Metals and Macroinvertebrate Communities in Bottom Sediment of Ekpan Creek, Warri, Nigeria. Jordan Journal of Biological Sciences. 2 (1): 1-8.

24. Olomukoro, J. O., Ezemonye L. I. N. (2006). Assessment of the macroinvertebrate fauna of rivers in southern Nigeria. African Zoology. 42(1): $1-11$

25. Omoigberale, M. O., Ogbeibu, A. E. (2010). Environmental Impact of Oil Exploration and Production on the Macrobenthic Invertebrate Fauna of Osse River, Southern Nigeria. Research Journal of Environmental Science. 4(2): 101-114.

26. Paterson C.G. and Fernando C.H. (1971) A comparison of a simple corer and an Ekman grab for sampling shallow water benthos. J. Fish. Res. Board Can., 28, 365-368.

27. Sengupta, M. and Dalwani, R. (2008) Benthic invertebrates - A crucial tool in biomonitoring of lakes. Proceedings of Taal 2007: The $12^{\text {th }}$ world lake conference: 95-98.

28. Sikoki, F. D. and Zabbey, N. (2005). Environmental gradients and benthic community of the middle reaches of Imo River, South-Eastern Nigeria. Environ. Ecol., 24(1): 32-36.

29. Umeham, S. N. (1989). Some aspects of the physico-chemical limnology of Lake Chad (southern sector). Journal of Aquatic Sciences, 4: 23 - 26.

30. Umeozor, O.C., (1995). Benthic fauna of New Calabar River, Nigeria. Trop. Freshwater Biol., 4: 41-51.

31. Victor, R. and Al-Mahrouqi, A. I. S. (1996). Physical, chemical and faunal characteristics of a perennial stream in arid northern Oman. Journal of Arid Environments, 465 - 476.

32. Victor, R. and Ogbeibu, A.E. (1989). Macro benthic Invertebrates of a stream flowing through farmlands in Southern Nigeria. Environ Pollut (Ser. A) 39: 337-349.

33. Victor, R. and Ogbeibu, A.E. (1991). Macro invertebrates' communities in the erosional biotopes of an Urban stream in Nigeria. Tropical Zoology. 4: 1-12 
34. Victor, R. and Onomivbori, O. (1996). The effects of urban perturbations on the benthic macroinvertebrates of a Southern Nigerian stream. In: Schiemer F, Boland KT, editors. Perspectives in tropical limnology. Amsterdam, Netherlands: SPB Academic Publishing. p. 223-38.

35. Zar. J.H. (1984). Biostatistical Analysis (2 $2^{\text {nd }}$ Ed.) Prentice Hall New Jersey, 717pp. 